\title{
The blind spots of trade impact assessment: macroeconomic adjustment costs and the social costs of regulatory change
}

\author{
Werner Raza \\ Austrian Foundation for Development Research, Vienna, Austria \\ Bernhard Tröster \\ Austrian Foundation for Development Research, Vienna, Austria \\ Rudi von Arnim \\ Department of Economics, University of Utah, Salt Lake City, UT, USA
}

Economic studies on trade liberalization typically highlight positive expected effects. This paper discusses those issues which are frequently neglected, but are nevertheless important for policy-makers. These are macroeconomic adjustment costs and social costs of regulatory change. Our discussion uses the most relevant studies on the economic effects of the Transatlantic Trade and Investment Partnership (TTIP) as reference points. We provide a rough estimate of macroeconomic adjustment costs of TTIP in the order of €33-60 billion over a 10-year transition period. Our analysis of regulatory change concludes that assessments have been biased and that the social costs of regulatory change due to TTIP might be substantial. Given the prominence of regulatory issues on the trade agenda, we call for full ex-ante regulatory impact assessment of future trade agreements.

Keywords: trade policy, trade impact assessment, non-tariff measures, macroeconomic adjustment costs, social costs

JEL codes: F13, F14, F17

\section{INTRODUCTION}

Since July 2013, the United States (US) and the European Union (EU) are negotiating a free trade agreement (FTA): the Transatlantic Trade and Investment Partnership (TTIP). This is the latest agreement in a series of bilateral trade negotiations in which the European Union has engaged during recent years. TTIP stands out in terms of its economic importance and with regard to its scope. It is indeed very comprehensive and includes a plethora of topics and issues, including: services and investment liberalization; public procurement; and cooperation in all matters of trade-related regulations with a view to dismantling so-called unnecessary regulation or harmonizing diverging regulations between the EU and US. Regulatory cooperation involves many sensitive areas of public policy, for instance consumer protection or social and environmental regulations.

As trade and investment within much of the industrialized world is already very open, trade liberalization in the conventional meaning of the term is only a minor issue in these negotiations. Average tariff rates between the EU and US already stand at less than 3 percent

Received 26 March 2015, accepted 17 August 2015 
for manufactured goods (Felbermayr et al. 2013b: 39). ${ }^{1}$ Nevertheless, proponents such as the European Commission argue that TTIP will give a boost to economic growth in the EU and US. The Commission estimates the potential economic gains due to TTIP at $€ 120$ billion for the EU economy, $€ 90$ billion for the US economy, and $€ 100$ billion for the rest of the world (European Commission 2013b: 2). With trade between the two regions already so open, the question emerges of where these benefits of TTIP might come from?

In order to answer this, the methodology of trade impact assessment needs to be scrutinized. The most commonly applied method of calculating the costs and benefits of trade liberalization is a computable general equilibrium (CGE) model. A CGE model falls within the general category of empirical economy-wide models. It is based on a social accounting matrix (SAM), which depicts detailed data on relations of production and distribution between the main socio-economic agents in an economy. The model adds behavioral relationships to the accounting; econometric evidence is applied to calibrate relevant parameters. The complete model can then be used to calculate counterfactuals in response to assumed shocks and policies - for example, tariff removal.

As previously stated, in the case of trade between the US and EU, most tariffs are already very low. Removing the remaining tariffs will have only limited effects. Most of the economic effects are expected to come from the elimination, harmonization, or mutual recognition of regulations. Therefore the focus of negotiations as well as modeling efforts lies on non-tariff measures (NTMs). These are procedures, laws, and regulations other than tariffs or quotas that impede trade in goods and services between two countries. In order to apply NTMs to a CGE model, these barriers need to be estimated, including what share of them is practically removable (or actionable). ${ }^{2}$

NTMs have become centre-stage with the new generation of trade agreements, which aim at what Robert Lawrence termed 'deep integration', that is, 'integration that moves beyond the removal of border barriers' (Lawrence 1996: 8). Deep integration trade agreements thus want to bring about the convergence and ultimately the harmonization of different regulatory systems in the countries that are party to the agreement. Economic theory would suggest that this will entail cost savings that will transfer into higher income and growth. Efforts towards deep integration started already with the Uruguay Round of the GATT, for example in the fields of intellectual property rights and government procurement. More recent efforts during the WTO Doha Round, particularly in the areas of investment liberalization, competition law, or domestic regulation in services, were however stifled by developing and emerging country opposition (Nölke/Claar 2012). Thus, efforts towards deep integration trade agreements were redirected to the bilateral and regional level, with the EU proactively pursuing this regulatory agenda in its bilateral trade policy since the mid 2000s. The regulatory agenda of the EU in these bilateral agreements has gradually become more comprehensive, with TTIP and CETA - the recently concluded trade agreement between Canada and the EU - arguably constituting the most advanced examples of deep integration trade agreements.

Thus, in this paper we do not focus on a discussion of the welfare gains usually estimated by CGE models as a consequence of tariff removal. Instead, we want to discuss aspects that are either not considered at all, or are considered in methodologically biased ways, but are

1. Felbermayr et al. (2013b), cited throughout the text, is a BMWT/ifo report.

2. A different (and much less common) method to calculate potential benefits is to assume that the trade agreement will reduce trade costs by an amount that is estimated with reference to existing trade agreements. A general equilibrium model of the world economy can then be used to calculate the economic gains from this reduction. The Bertelsmann/ifo report (see footnote 4 for reference) proceeds along these lines. 
nevertheless highly relevant for policy-makers. These include macroeconomic adjustment costs and the social costs of regulatory change. The former refer to costs that relate in particular to (i) the public budget balance and (ii) the level of unemployment. The latter asks the question of what kind of social costs (and benefits) might be expected from regulatory changes, that is, from planned removals or alignments of NTMs. In addition, we point to another social cost of trade accruing from investment arbitration. We attempt to show that the treatment of these issues in trade impact assessments is highly insufficient. Our discussion uses the most widely cited studies in the public debate on the economic effects of TTIP as reference points. Before moving on to the discussion of the aforementioned issues, the remainder of this introduction therefore briefly discusses the projected benefits of TTIP by the four most relevant trade impact assessments: from ECORYS (Berden et al. 2009), from CEPR (Francois et al. 2013), and from CEPII (Fontagne et al. 2013), ${ }^{3}$ as well as from Bertelsmann/ifo (Felbermayr et al. 2013a). ${ }^{4}$

The message from these studies is clear: all EU member states and the USA will benefit from TTIP. (Table 1 presents a quick overview.) The ECORYS study (Berden et al. 2009) produces NTM estimates which are then used as inputs to a CGE model in the same study, and later used in the studies of CEPR (Francois et al. 2013) and CEPII (Fontagne et al. 2013). ${ }^{5}$ ECORYS and CEPR employ the same model, which is based on the popular Global Trade Analysis Project (GTAP) model. The CEPII model, called MIRAGE, differs in the details, but rests on the same conceptual foundations. The fourth study, Felbermayr et al. (2013a) - financed by Bertelsmann Foundation and conducted by the ifo institute - estimates a gravity trade model, and employs a quite different simulation strategy (see footnote 2). While the procedures differ in the details, all four models seek to describe long-run economic developments and thus share important similarities regarding causal assumptions.

Given the similar data base (GTAP 7 and 8) and the closely related methodological approaches, it is not surprising that ECORYS (Berden et al. 2009), CEPR (Francois et al. 2013) and CEPII (Fontagne et al. 2013) report gains in real income and trade flows within similar ranges for all participating countries. The variations in the quantified effects can be attributed to variations in the approach to calculate tariff equivalents of NTMs and specific modifications of the CGE model. In contrast, the Bertelsmann/ifo findings (Felbermayr et al. 2013a) show the most pronounced benefits due to the larger bilateral trade effects of TTIP, higher implied trade costs, and the assumption that trade costs are resource consuming.

All studies define various scenarios by comparing policy changes to a baseline calibration. Policy changes are phased in over an implementation period of, typically, 10 years. In Table 1, we consider the 'limited scenario' in ECORYS (Berden et al. 2009), the 'ambitious experiment' in CEPR (Francois et al. 2013) and the 'reference scenario' in CEPII

3. Berden et al. (2009) is an ECORYS report, Francois et al. (2013) is a CEPR report, and Fontagne et al. (2013) is a CEPII policy brief.

4. The Bertelsmann Foundation has published a study on TTIP with two parts. Our analysis is based in particular on part 1: macroeconomic effects. This report is listed in the references as Felbermayr et al. (2013a) and referred to as Bertelsmann/ifo throughout the main text. However, the Bertelsmann/ifo (Felbermayr et al. 2013a) report is mainly based on the comprehensive BMWT/ifo (Felbermayr et al. 2013b) findings, contracted by the German Federal Ministry for Economic Affairs and Technology (BMWT). Thus, results of Chapter II and III of the BMWT/ ifo study are used to allow for a detailed comparison given that Bertelsmann/ifo (Felbermayr et al. 2013a) published only selected results. We aggregate results to a trade- and GDP-weighted EU-27 average, if possible.

5. CEPII uses the ECORYS estimates in addition to its own (see Fontagne 2013). 


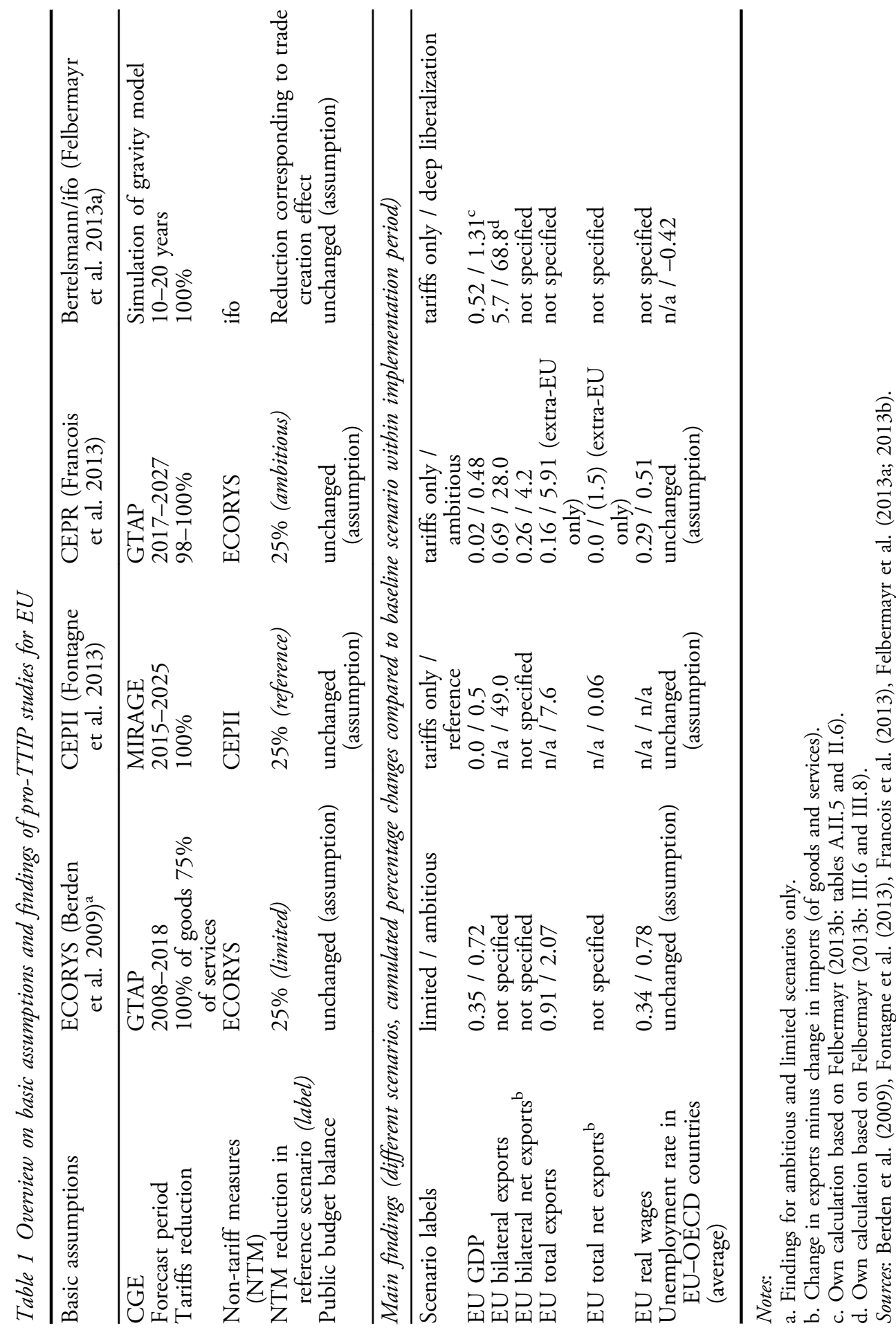


(Fontagne et al. 2013) as major scenarios. In all of these scenarios, a cut in trade costs of roughly 25 percent is assumed. In the Bertelsmann/ifo study (Felbermayr et al. 2013a), the 'comprehensive liberalization scenario' is regarded as the most important simulation. This experiment is also comparable to the 'NTB-scenario' in BMWT/ifo (Felbermayr et al. 2013b: 92) in which trade costs are also cut by 25 percent. We present changes in real GDP, trade flows and distribution among sectors in the two economic areas as reported by the studies. In addition, the implications for real wage and employment can be summarized. Table 1 provides an overview with additional details on the assumptions and specifications, and a summary of the main findings.

It should be stressed that the estimated numbers are positive, but small. GDP and real wage increases are estimated by most studies to range from 0.3 to 1.3 percent. Unemployment is expected to either remain unchanged (by assumption), or in one case the unemployment rate in EU-OECD countries will decline by 0.42 percentage points. EU total exports would increase by 5-10 percent. If net exports are considered, changes are however much smaller. All of these changes regard the long run, which means that they will accrue over a transition period of 10 to 20 years. Put differently, annual effects during the transition period will be a fraction of these reported numbers.

In Section 2, we discuss potential macroeconomic adjustment costs. Section 3 considers the social costs of regulatory change in detail, while Section 4 considers those of investment arbitration. A final section (5) concludes with some policy recommendations.

\section{MACROECONOMIC ADJUSTMENT COSTS}

Trade agreements imply a multitude of changes for the government and firms, as well as households. These changes may be both positive and negative, and adaptation to them will confer benefits as well as costs upon society and particular social groups. Benefits and costs may be of a transitory or more permanent nature. In the former case, these costs are usually labeled as adjustment costs. These transitory adjustment costs are to some extent recognized by conventional impact assessments while it is generally assumed that trade agreements do not entail long-term costs for society.

In the following, we intend to focus our attention on types of adjustment costs that were either underestimated by the four scrutinized TTIP studies, or were neglected outright. A class of adjustment costs refers to macroeconomic variables, which are crucial to economic policy in any advanced country. These are: (i) the public budget balance, and (ii) the level of unemployment. In addition, we provide a rough estimate of the likely magnitude of some of these costs (Section 3).

\subsection{The public budget balance}

Public budgets are impacted by trade liberalization both on the income and expenditure side. It is thus noteworthy that all of the scrutinized studies assumed that trade liberalization will not have an impact on the balance of the public budget and that necessary adjustments on the income and expenditure side will not have any negative effects. We will here focus on the income side, and take up the expenditure side when discussing labor market adjustment costs in the next section.

A straightforward consequence of trade agreements is the reduction, if not elimination, of tariffs. The latter, however, form part of public revenues. Thus, all other things equal, trade liberalization will reduce public revenues and hence increase the government deficit. 
While tariffs still account for up to 40 percent of public income in many LDCs, public revenue from tariffs in the EU and US is rather small. However, tariff revenues are an important income source for the EU budget. In 2012, roughly 12 percent of the EU budget was financed via tariff revenues. In 2012, according to the European Commission (2013a: 55), tariffs levied on US imports amounted to $€ 2.6$ billion, or 12 percent of total EU tariff revenue. Depending on the simulation scenario, CEPR reports (Francois et al. 2013: 54) reduced tariff income between $€ 5.4-7.3$ billion on a yearly basis by 2027, that is, after the full implementation of TTIP. Thus, if we conservatively estimate the long-term loss of tariff income to the EU to be in the range of $€ 5$ billion per year, of which 75 percent ( $€ 3.75$ billion) goes into the EU budget as traditional own resources, that amounts to a permanent annual revenue loss of at least 2.7 percent for the EU budget in its current magnitude. Though it is plausible that an increase of EU exports and thus output because of TTIP will also lead to an increase of Gross National Income (GNI) own resources for the EU budget, which will at least partially compensate for the lost tariff income, we would argue that in the short to medium term, a net loss to the EU budget will be likely. This owes to the fact that tariff revenue losses will happen immediately, while EU exports will only gradually increase over time. Thus, we would expect a need to adjust the EU financial framework over the short and medium term, after TTIP eventually enters into force. Though the European Commission in its impact assessment report does not expect any problem in compensating tariff losses by other funds (European Commission 2013a: 55), we would argue that although 2.5 percent seem to be a manageable amount, in the prevailing austerity environment the political will of member states to give more money to the EU budget might be limited.

\subsection{The level of unemployment}

The potential benefits of TTIP can only be generated by a sectoral reallocation of the production factors labor and capital. This long-term process necessarily involves job displacements in the short to medium run as sectors facing strong import competition after liberalization have to reduce output and employment. It is widely recognized that adjustment costs are distributed unequally as certain individuals or groups, for instance older and less skilled workers in manufacturing, bear a substantial burden of trade-related adjustments (OECD 2005). It is also likely that some output is foregone until all production factors adjust to the new equilibrium, which in consequence will lead to less employment, income, and tax revenues for some period of time.

In general, trade-related adjustment costs include private costs for labor such as unemployment, retraining costs, or obsolescence of skills, as well as adjustment costs for capital, for instance investments to become an exporter. In addition, increased spending for unemployment benefits, retraining, and social security programs, as well as lower tax revenues, are likely to constrain the government budget (Laird/de Córdoba 2006). The inclusion of potential adjustment costs into an assessment of trade agreements is essential as it reveals possible winners and losers from trade liberalization beyond average welfare gains as well as the uneven distribution of possible benefits and costs within and between economies in a trade agreement. In addition, economic shocks during the long-term adjustment process (10-20 years) might increase the cost of adjustment and potentially reduce or eliminate gains from trade agreements.

The studies discussed here do not consider potential negative effects on labor markets. Unemployment is seen as a temporary phenomenon during an adjustment process that is overcompensated by new jobs and higher income streams in the long run. For example, 
the CEPR study does not model unemployment at all in order to '... gather clearer insights on what would be the impact of the agreement on labor markets in the longrun' (European Commission 2013b: 15). In other words, the models simply assume either full or constant employment.

The BMWT/ifo report (Felbermayr et al. 2013b: 14) suggests that all adjustment processes are completed within five to eight quarters. The authors also refer to Trefler (2004) regarding the speed of adjustment. Trefler (2004), who analysed adjustment processes in Canada after the free trade agreement (FTA) with the US in 1988, found evidence for likely aggregate welfare gains but reported substantial job losses associated with the FTA, that is, 12 percent for the import-competing industries and 5 percent for manufacturing. The author (ibid.: 879 , emphasis added) suggests, 'albeit not conclusively, that the transition costs were short run in the sense that within ten years the lost employment was made up for by employment gains in other parts of manufacturing,' indicating a longer transition period at least for the manufacturing sector. Evidence from changes in labor markets after the North American Free Trade Agreement (NAFTA) also raises questions, whether trade-related negative impacts are only transitory or not (see Grumiller 2014).

In 2005, the OECD evaluated trade-adjustment costs in the labor markets of its member states. First, adjustment costs for trade-displaced workers are moderately higher than for other job losers due to slower re-employment (EU) and lower wages in new jobs (US). Second, displacements in EU manufacturing are more likely to hit older, less skilled workers. However, differences in terms of effects upon other displaced workers are limited. Finally, many displaced workers find a new job in the same industry, but with slightly lower wages. Workers that switched industries even faced substantially lower earnings, particularly in the US. Francois et al. (2011: 224) emphasize that labor bears the bulk of adjustment costs und that 'trade reform can add significantly to job displacement if undertaken when the job market is already under stress, such as situations of economic recession or major structural change.'

Thus, one way to gauge possible negative effects is through measurement of displacements. CEPR (Francois et al. 2013) offers one such calculation, and we will take it as a starting point here. A displacement index indicates how many workers move across sectors in order to regain employment. However, the indicator accounts for net reallocations among sectors in the EU and US only, and excludes reallocations within sectors. The estimated displacement must therefore be seen as a quite conservative (or optimistic) assessment.

The study suggests that in the EU fewer than 7 (less skilled) workers per 1000 have to switch to another sector, while in the US it is fewer than 5 workers per 1000. This is not surprising, given the overall limited effect of TTIP on output on the one hand, and the trade versus labor market composition on the other. In 2012, trade in goods amounted to 75 percent of total EU trade volume but less than 30 percent of the workforce was employed in the related sectors (Eurostat). Still, when putting the displacement number into perspective, within the EU between 0.43 and 1.1 million workers would be affected by such a transition. Although CGE models foresee an improvement for people due to a switch from low to more productive sectors with higher wages, the empirical evidence shows that a switch to another industry typically includes a loss in income (OECD 2005). CEPR also argues that a displacement index around 0.6 percent is relatively small compared to normal labor turnover in the EU of more than 3.7 percent since the crisis in 2008 (Francois et al. 2013: 78). As mentioned above, the displacement index does not capture all relevant changes in labor markets 'as displacement across firms is widely ignored in this literature [on adjustment costs in CGE models]' (Francois et al. 2011: 226). However, reallocation of jobs mainly happens within sectors, given the heterogeneity of 
firms within a sector (OECD 2005: 36). This is also true for less competitive sectors that lose in terms of average productivity, output, and real wages.

Taking into account the high risk of long-term unemployment faced by older and less skilled workers in manufacturing once displaced (OECD 2005), and the reality of increasing long-term unemployment in OECD countries, a substantial part of the displaced workforce might be worse off with TTIP, even if average real wages as a whole are expected to increase. Furthermore, the assumption of no long-term unemployment in the case of the EU also implies sufficient labor mobility across EU member states. Given the diverging wage levels within the EU, labor movements from higher to lower wage countries are however most unlikely (see also EuroMemo Group 2014). Overall, it has to be stated that none of the studies provides a thorough estimation of possible adjustment costs in labor markets. However, such an assessment would be crucial. A simple hint towards positive long-term effects understates the need for policy measures to mitigate the risk of welfare and employment losses for specific groups and individuals. In particular, the distressed situation in several European labor markets increases the need for the assessment of TTIP's potential adjustment costs even more.

For our calculation of potential macroeconomic adjustment costs in the next section, we take these displacement numbers as a starting point. It should be emphasized again that this is a very conservative estimate: the index is calculated from a model that assumes overall full employment; the index does not capture within-sector displacements and associated risks specifically for less skilled workers; and the 'true' displacement might be much larger in the current precarious economic condition of Europe (EuroMemo Group 2014). In summary, none of the studies considers adjustment costs; instead, they assume full employment in the long run. However, adjustment costs will arise, and policy-makers should be prepared to mitigate the risk of welfare and employment losses for specific groups and individuals. The following section suggests how large these costs might be.

\subsection{Potential macroeconomic adjustment costs: a rough calculation}

After discussing the different types of macroeconomic adjustment costs that are relevant for the TTIP negotiations, we would like to illustrate the likely magnitude of these costs by offering a rough calculation. The calculation includes loss of public revenue and the costs of unemployment. It is our objective (i) to provide a conservative estimate and (ii) to provide a plausible number that indicates the order of magnitude we will likely have to tackle. The loss of public tariff revenue is estimated on the basis of the reported number on tariff income from US imports in 2012 (European Commission 2013a), representing the lower bound, and the estimated tariff income loss in 2027 from the most ambitious liberalization scenario of the CEPR study (Francois et al. 2013), thereby assuming that over a 10-year period annual losses would reach the upper bound of $€ 5.4$ billion in 2027. Unemployment numbers were also taken from labor displacement estimates of the CEPR study (ibid.), and assumed to be in the range of 430 000-1100 000 within a 10-year period. Compared to the reported US job losses due to NAFTA we consider these numbers to be plausible (see Grumiller 2014). However, given the difficult labor market situation in many EU member states and the evidence from the empirical literature (see discussion above), we assume that 10 percent of the displaced persons will not find other (full-time) employment and will thus become long-term unemployed. We assume that the average length of their unemployment is 5 years during the 10-year implementation period of TTIP. In accordance with most national unemployment benefit schemes, we further assume that during the first year workers will receive a higher net replacement 
rate ( 66 percent) than for the following 4 years ( 41 percent). For annual wages and replacement rates we use averages derived from OECD statistics. In contrast, we assume that 90 percent of displaced workers will become re-employed after 6 months on average, without a loss compared to their pre-TTIP income level - again, we are on the optimistic side.

We also consider the foregone public income from taxes and social contributions due to unemployment. Even if, during the transition period, new jobs will be created in export sectors, the net effect on the public balance is likely negative. Labor expansion in the EU due to TTIP will mainly happen in services sectors, while manufacturing employment will sink (see Francois et al. 2013: tables 34 and 36). Since in the EU average labor compensation per employee in manufacturing is about 20 percent higher than in the total economy (Veugelers 2013: 19), comparatively less tax and social security contributions will flow into the public treasury.

Upon that basis, we calculate a lower and an upper bound of cumulative adjustment costs of TTIP during the 10-year implementation period (see Table 2). Our lower bound is $€ 33$ billion, our upper bound $€ 60$ billion, or respectively, 0.23 percent and 0.42 percent of EU GDP. On an annual basis that would amount to $€ 3-6$ billion. Of these, between $€ 0.5$ and $€ 1.4$ billion will come from unemployment benefits, and $€ 0.4-1.0$ billion from foregone income from taxes and social contributions.

Though small relative to EU GDP, these additional costs might be a burden for public budgets, particularly in those EU countries that are currently implementing severe austerity programmes. In addition, it is questionable whether the respective EU facilities - that is, the European Globalisation Adjustment Fund and the European Social Fund with budgetary endowments of $€ 150$ million and $€ 10$ billion per annum - are in a position to efficiently cope with this additional challenge. Given the historically high levels of unemployment in many EU member states, manifold needs to fund employment policies do already exist and will have to compete for funds with TTIP adjustment policies. An increase of financial resources for these funds should thus be seriously considered by EU policy-makers.

It should however be clear that the effectiveness of these instruments in coping with trade adjustment will be limited. Often, the affected companies will not openly communicate the real reasons for shutting down a factory or relocating it. Thus, a monitoring system needs to be implemented which surveys the regional effects of trade liberalization. In addition, access to funding at the EU facilities is quite onerous (see GHK 2011), resulting so far in an underutilization of available monies. ${ }^{6}$ This calls for reform of the administrative workings of the instruments with a view to making access to funds for affected workers much easier.

\section{THE SOCIAL COSTS OF REGULATORY CHANGE}

A type of adjustment cost conveniently ignored, but particularly relevant in the case of TTIP, refers to the regulatory change resulting from the agreement. This type of cost appears in various forms, depending on the type of regulatory change employed. First, harmonization of NTMs - for example, technical standards - though leading to longterm cost savings for companies, will imply both a short-term adjustment cost for public institutions and for firms required to align their administrative procedures, production

6. Disbursements of the fund during the period 2007-2013 amounted to just 17 percent of the maximum amount available. See http://ec.europa.eu/social/BlobServlet?docId=7322\&langId=en (accessed 1 September 2014). 


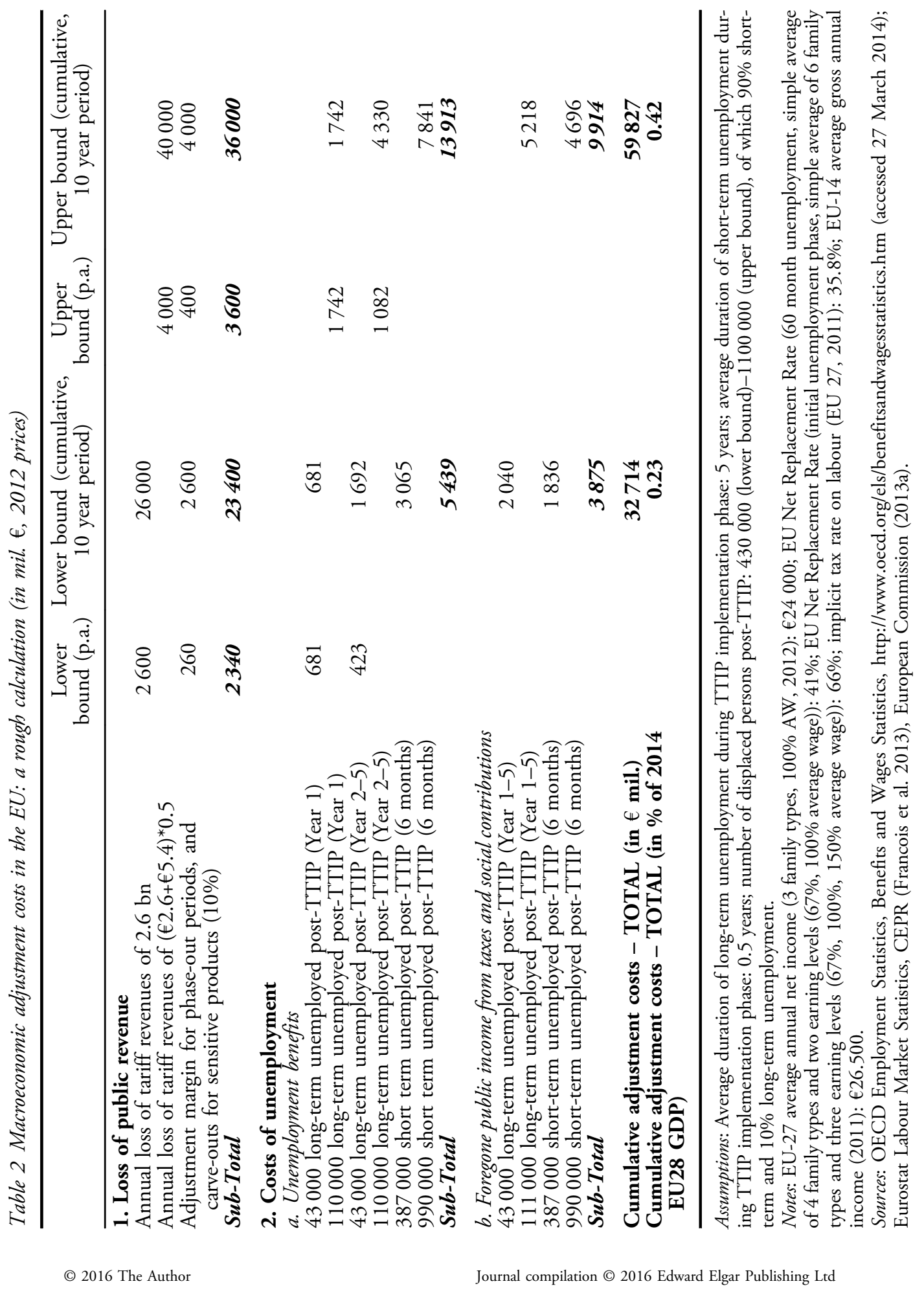


processes, and products to the new standards. Second, mutual recognition of regulations and standards between trading partners will inter alia increase information costs for consumers, as the latter will be confronted with a more complex and potentially less transparent multiplicity of permissible standards, for example on goods and services. Third, the elimination of NTMs will result in a potential welfare loss to society, in so far as this elimination threatens public policy goals (for example, consumer safety, public health, environmental safety), which are not taken care of by some other measure or policy. Though subject to considerable uncertainty, these types of adjustment costs might be substantial and require careful case-by-case analysis. As we will see in the following, although the social costs of regulatory change are of particular relevance for the analysis of TTIP because of its emphasis on regulation issues, they have not been dealt with properly by the four scrutinized TTIP studies.

As already mentioned, around 80 percent of the estimated economic benefits of TTIP accrue from the dismantling of NTMs or their alignment. In their assessment of NTMs, three out of the four scrutinized TTIP studies draw on the work of ECORYS (Berden et al. 2009). The fourth study, Bertelsmann/ifo (Felbermayr et al. 2013a), employs a somewhat different methodology, but essentially shares the same underlying philosophy with regard to NTM reduction. NTMs are basically understood as 'all non-price and nonquantity restrictions on trade ... . This includes border measures (customs procedures, etc.) as well as behind-the-border measures flowing from domestic laws, regulations and practices ...' (Berden et al. 2009: xiii). The study focuses on both elimination of NTMs and of regulatory divergence, that is, the existence of different regulations with the same purpose, for example technical standards for turn signals in the EU and US. The latter should be aligned, for example by negotiating a common new standard. Mutual recognition of standards is however not explicitly mentioned. These NTMs are understood to hinder the deep economic integration of the EU and US economies. Thus, their elimination or alignment to some common standard becomes desirable, as this would facilitate further economic integration. ECORYS then purports to estimate the quantitative significance of these NTMs by way of an elaborate procedure. Most importantly, in a survey companies and experts were asked to assess the level of restrictiveness of NTMs in bilateral trade. Upon that basis, indexes were constructed that were then used to estimate the impact of NTMs on trade and investment flows, or, in other words, to calculate trade cost equivalents of existing NTMs. ECORYS (Berden et al. 2009: 23) arrives at an average trade estimate of NTMs across sectors of 17 percent. This is a multiple of the 3-4 percent estimates of alternative authoritative studies (see for example Anderson/van Wincoop 2004). In a further step, again with the help of experts, levels of actionability were established, that is, assessments with regard to 'the degree, to which an NTM or regulatory divergence can potentially be reduced ...' (Berden et al. 2009: 15). Actionability levels were determined to range from 35 percent to 70 percent, with the average for the EU at 48 percent and for the US at 50 percent. In a last step, these actionability levels were taken as inputs for the CGE scenario estimations in the three studies by ECORYS (Berden et al. 2009), CEPR (Francois et al. 2013) and CEPII (Fontagne et al. 2013). In the optimistic scenarios, a reduction of actionable NTMs of 50 percent and 25 percent were typically assumed.

Not surprisingly, the overall welfare effect, which is computed by the CGE simulations, is very sensitive to the assumed actionability level. The higher the actionability of NTMs, the higher the welfare gains. Actionability is defined as 'the degree to which an NTM or regulatory divergence can potentially be reduced (through various methods) by 2018, given that the political will exists to address the divergence identified (Berden et al. 2009: 15, emphasis added). Actionability thus depends on political will, which however is assumed as given. This definition is highly problematic, as the political process is 
effectively assumed away, and substituted for by an ad-hoc assessment of a sample of mostly business-related experts, which we would suspect to exhibit a certain tendency to both overestimate actionability levels and cost savings to companies. Thus, the determination of actionability levels is basically a more or less sophisticated guess of a group of persons with vested interests, and is not grounded on any kind of robust methodology.

This bias in the selection of respondents is clearly visible in the ECORYS study (Berden et al. 2009). The study has primarily asked firms (5500 in business survey) and business associations in the EU with regard to the restrictiveness of US regulations and vice versa. One should however suppose that firms and business associations have a tendency to overestimate the cost of complying with foreign standards, as they want to lower the cost of doing business abroad, and thus have a vested interest. In order to counterbalance this and increase the robustness of results, at the very least, one should have also asked US firms on their assessment of the cost of complying with US regulations, and EU firms on EU regulations. In addition, one might have asked experts with diverse professional backgrounds, for example people representing labor interests, consumers, human rights groups, etc., for their assessment.

In terms of the robustness of its results, the ECORYS study states that it has crosschecked its restrictiveness estimates with other existing measures, in particular the OECD FDI restrictiveness index (Berden et al. 2009: 16). However, cross-checking the ECORYS NTM indexes with the OECD FDI restrictiveness index amounts to comparing apples with oranges. The latter focuses on four specific types of discriminatory measures: equity restrictions, screening and approval requirements, restrictions on foreign key personnel, and other operational restrictions - such as limits on the purchase of land or on the repatriation of profits and capital (Kalinova et al. 2010). Though there may be partial overlaps, the two indices essentially refer to different types of measures: while the ECORYS NTM indexes refer mostly to behind-the-border measures, which typically are non-discriminatory, the FDI restrictiveness index refers primarily to specific types of discriminatory measures. In sum, it is questionable whether the FDI restrictiveness index is a suitable vehicle for a robustness check of ECORYS's NTM indexes.

Also, the magnitude of income effects from NTM reductions in the ECORYS study is inflated by a factor of four for the EU and three for the US, by assuming that NTMs will not be aligned sector by sector, but economy-wide; that is, reductions of NTMs in all sectors of the EU and US economies will occur simultaneously (Berden et al. 2009: 27). This multiplication is justified by ECORYS on the grounds of sector interlinkages - that is, cost savings from NTM alignments - which are passed on to other sectors and thus reduce input costs and prices of end products. Similarly, the simultaneous reduction of NTMs across all sectors has a strong effect on output and exports, and investment in the affected sectors is expected to increase. We do not dispute that sector linkages have a role to play. If, however, one makes the more realistic assumption that as a result of the TTIP negotiations NTM reductions or alignments will occur only in a subset of sectors - that is, in some sectors, while not in others, because of (for example) national security or for consumer protection reasons - the effects on income, output, and exports will shrink substantially.

In addition to the many criticisms we have just outlined on the details of the methodology used to assess the cost savings of regulatory alignment, our principal concern here relates to the methodological approach in more general terms. First and foremost, the ECORYS study implicitly assumes that a substantial dismantling and alignment of NTMs between the EU and the US is possible without a change to the regulatory quality, that is, the ability of a certain regulation or standard to safeguard a defined public policy goal. Only upon that basis, ECORYS is able to restrict itself to estimating the savings to 
companies because of NTM removal, while completely neglecting the social costs concomitant with that removal. Consequently, it arrives at generally small but positive economic gains.

Overall, we think that using such an approach is not warranted, given that the ECORYS study derives very high gains from regulatory alignment in exactly those sectors - for example, chemicals, cosmetics and pharmaceuticals, or food and beverages - where substantial and partly incommensurable differences in regulatory approaches and standards between the EU and US exist. Any dismantling or alignments must have an effect on regulatory standards and thus confer a cost or benefit upon that society, depending on whether it ends up with a lower or higher standard. In general, it must be recognized that a change in a standard will always alter the distribution of costs and benefits between social actors, for example between firms and consumers. Alternatively, firms might also be unevenly affected by regulatory change, the latter for example possibly favoring big companies while inferring an additional burden on small companies.

Undoubtedly, NTM dismantling will make sense in some individual cases - for example because the dismantled regulation has proven ineffective in serving a particular public policy goal or has existed for purely historical reasons - but must not be assumed as a general rule. Typically, regulations serve a public policy goal. If that regulation is changed - either dismantled or aligned to some other standard, its effectiveness in serving the public policy goal will eventually be affected. This might confer a social benefit, if the new standard is higher than the old one, or a social loss, if the new standard is lower than the old one or has been eliminated without substitution. The latter case is obviously the focus of the ECORYS study. Though without doubt difficult, the study does not make any effort to quantify social losses, but exclusively looks at the benefits of NTM reductions to companies and the economy. Social losses might come in the form of temporary adjustment costs, for example for harmonizing and implementing legislation, or be of a longterm nature to society, for example if standards for poisonous chemicals were relaxed and resulted in higher public health costs because of a higher incidence of allergies amongst the population. This non-consideration of social costs is especially problematic, as the study estimates the trade cost reductions of TTIP to be particularly high in sensitive sectors such as chemicals, pharmaceuticals and cosmetics, food and beverages, or automotives (see Berden et al. 2009: 23, table 4.2). Thus, in order to arrive at its optimistic welfare estimations, strong reductions or alignments of NTMs in precisely those sectors are necessary, where the safeguarding of public policy goals is perhaps most crucial. For instance, above-average actionability levels were chosen for the sectors chemicals, cosmetics, and food and beverages (ibid.: 16, table 3.3).

By way of conclusion, our discussion of the assessment of the effects of NTM has shown that the scrutinized study estimates the costs of regulation to be extremely high, thus suggesting large cost savings to the economy via regulatory alignment, while it is conveniently assumed that any change to a regulation by way of reduction, elimination or alignment will not have any impact on regulatory quality. The critical academic literature however provides reasons to believe that things might turn out to be exactly the other way round. Regulatory costs have been shown to be generally very small, even for ambitious projects such as the EU chemicals regulation REACH (Ackerman/Massey 2004), while the benefits of regulation for society are often very high, though difficult to express in purely monetary terms, or as Ackerman/Heinzerling (2004) have put it, they are in effect 'priceless.' But even if one subscribed to conventional social cost-benefit analysis, the results of typical evaluation studies such as those undertaken by US regulatory agencies would suggest that the social benefits of regulations clearly outweigh their economic costs. A review of all economically significant US regulations over the period 2000-2012 conducted 
by the Office of Information and Regulatory Affairs (OIRA) has come to the conclusion that benefits outweigh costs in every year and do so by a factor of more than six on average over the whole period (OIRA 2010, cited in Myant/O'Brien 2014: 29).

It should thus be expected that a systematic consideration of the social benefits of regulation would substantially change the overall balance of any assessment of the costs and benefits of the removal or alignment of NTMs. In the best of cases, regulatory alignment in a trade agreement might lead to an improvement of regulatory standards. As regulations are predominantly seen as a cost to business, in TTIP as well as most other trade agreements, we would however contend that risks for downward leveling of regulation should be expected to be preponderant. Given the high social benefits of regulation, even minor regulatory changes might dwarf the economic gains of most trade agreements, or even worse, shift the overall balance into the negative.

\section{THE SOCIAL COSTS OF INVESTMENT ARBITRATION}

One of the most controversially debated features of TTIP is investor-to-state dispute settlement (ISDS). None of the four scrutinized TTIP impact studies has anything to say on this. While a comprehensive discussion of ISDS is beyond the scope of this study, it should be evident that ISDS, if included in the final TTIP agreement, would eventually lead to litigation cases, which could entail compensation claims against the EU. This indeed seems to be quite likely, given the exceptionally high level of FDI between the EU and the US. The bilateral FDI stock stood at $€ 2400$ billion in 2011 (European Commission 2013a: 9), annual FDI inflows from the US to the EU amounted to roughly $€ 80$ billion in the same year.

As a matter of fact, a strong increase in ISDS litigation has been observed during the last 2 decades. According to UNCTAD, in 2012 alone 58 new cases were initiated, bringing the total number of known cases (concluded, pending, or discontinued) to 514 by the end of 2012 (UNCTAD 2013: 110). 23 percent or 123 of these were filed by US investors, with EU investors from the Netherlands (50 cases), the UK (30), and Germany (27) following (Bizzarri 2013: 25). In some instances, countries have faced claims going into billions of euros, with the highest award of US $\$ 1.77$ billion issued against Ecuador in 2012 (UNCTAD 2013: 111). According to UNCTAD, host countries - both developed and developing - have experienced ISDS claims being used by foreign investors in unanticipated ways. A number of recent cases have challenged measures adopted to act in the public interest, and policy-makers in some countries have found that international investment agreements can unduly constrain their domestic regulatory prerogatives.

Given both the high amount of bilateral investment between the US and the EU and the proactive attitude of US and EU investors in using ISDS so far, it seems safe to assume that investors will use ISDS as a mechanism to discipline governments on both sides of the Atlantic. Thus, in case of successful litigation against the EU, compensation payments will have to be made. While it is of course not possible to provide an estimate on the timing and magnitude of such payments, from the experience so far it should be clear that they can be substantial, and would present an additional burden on public budgets. A further and potentially even more important consequence of an ISDS mechanism in TTIP could come in the form of a threat or chill effect to governments. ISDS gives investors an additional and powerful legal remedy, thus improving their bargaining positions vis-àvis governments on issues of regulation. That might lead governments either to abstain from enacting public regulation outright for fear of being challenged before an 
international investment arbitration panel. Or alternatively, it might induce governments to accept forms of regulation, which privilege investor interests over the interests of the general public. Either case would of course imply a welfare loss for society.

\section{CONCLUSIONS AND POLICY RECOMMENDATIONS}

By scrutinizing the four most widely cited TTIP impact studies, we have purported to show that conventional trade impact analysis neglects a careful assessment of adjustment costs and the social costs of regulatory change. While this can be explained by the biases of the applied neoclassical theoretical framework, it must be stressed that in particular adjustment costs relating to the EU budget and labor market policies (retraining, unemployment benefits) might be substantial, and need to be dealt with at the political level (for an in-depth discussion of the methodological biases, see Raza et al. (2014: ch. V).

The social costs of regulatory change are by their very nature difficult, if not partially impossible to quantify. Nevertheless, they can be very large and thus require careful analysis, in particular in those areas where they relate to public health and safety, and consumer and worker protection, as well as environmental safety. It should also be stressed that a methodological approach for such an impact analysis is needed, which is characterized by inter-disciplinarity, transparency, and the participation of all affected stakeholders. Conventional cost-benefit approaches have proved inept at tackling the methodological challenges inherent in such studies (Ackermann 2008). Instead, they must be complemented by other approaches, for instance social multi-criteria analysis, that are able to deal with the problems of incommensurability and fundamental uncertainty, both of which are expected to appear in such an evaluation exercise.

The potential social costs of investment arbitration come from two sources. The first is obviously compensation payments levied upon governments by arbitration panels. The second refers to chill effects which induce governments to refrain from effective regulation in the public interest for fear of becoming liable under investment arbitration.

In sum, with regulatory issues ranging among the top priorities of the current trade agenda, comprehensive ex-ante regulatory impact assessments should become an integral part of future trade impact assessment exercises in the European Union.

\section{REFERENCES}

Ackerman, F. (2008): Poisoned for Pennies: The Economics of Toxics and Precaution, Washington, DC: Island Press.

Ackermann, F., Heinzerling, L. (2004): Priceless: On Knowing the Price of Everything and the Value of Nothing, New York and London: The New Press.

Ackerman, F., Massey, D. (2004): The true costs of REACH, A study performed for the Nordic Council of Ministers, TemaNord 2004:557, Copenhagen, URL: http://www.ase.tufts.edu/ gdae/Pubs/rp/TrueCostsREACH.pdf (accessed 24 August 2014).

Anderson, J.E., van Wincoop, E. (2004): Trade costs, in: Journal of Economic Literature, 42/3, 691-751.

Berden, K., Francois, J., Thelle, M., Wymenga, P., Tamminen, S. (2009): Non-tariff measures in EU-US trade and investment: an economic analysis, in: ECORYS, Study for the European Commission, Directorate-General for Trade, URL: http://trade.ec.europa.eu/doclib/docs/ 2009/december/tradoc_145613.pdf (accessed 25 August 2014).

Bizzarri, K. (2013): A brave new transatlantic partnership: the proposed EU-US Transatlantic Trade and Investment Partnership (TTIP/TAFTA) and its socio-economic and environmental consequences, Report, Seattle to Brussels Network, NGO Corporate Europe Observatory, Brussels. 
EuroMemo Group (2014): EuroMemorandum 2014, URL: http://www2.euromemorandum.eu/ uploads/euromemorandum_2014.pdf (accessed 24 March 2014).

European Commission (2013a): Impact assessment report on the future of EU-US trade relations, Staff Working Document, SWD(2013) 68 final, Strasbourg, URL: http://trade.ec.europa.eu/ doclib/docs/2013/march/tradoc_150759.pdf (accessed 26 March 2014).

European Commission (2013b): Transatlantic trade and investment partnership: the economic analysis explained, URL: http://trade.ec.europa.eu/doclib/docs/2013/september/tradoc_151787.pdf (accessed 24 March 2014).

Felbermayr, G.J., Heid, B., Lehwald, S. (2013a): Transatlantic trade and investment partnership (TTIP): who benefits from a free trade deal? Part 1: macroeconomic effects, Report, Bertelsmann Foundation, URL: http://www.bfna.org/sites/default/files/TTIP-GED\%20study\%2017June\% 202013.pdf (accessed 24 March 2014).

Felbermayr, G.J., Larch, M., Flach, L., Yalcin, E., Benz, S. (2013b): Dimensionen und Auswirkungen eines Freihandelsabkommens zwischen der EU und den USA, Report commissioned by the (former) German Federal Ministry for Economic Affairs and Technology, BMWT/ifo Institute.

Fontagne, L., Gourdon, J., Jean, S. (2013): Transatlantic trade: whither partnership, which economic consequences?, Policy Brief, 1, CEPII, September.

Francois, J., Jansen, M., Peters, R. (2011): Trade adjustment costs and assistance: the labour market dynamics, in: Jansen, M., Peters, R., Salazar-Xirinachs, J.M. (eds), Trade and Employment: From Myths to Facts, Geneva, 213-252.

Francois, J., Manchin, M., Norberg, H., Pindyuk, O., Tomberger, P. (2013): Reducing transatlantic barriers to trade and investment: an economic assessment, Final Project Report, Centre for Economic Policy Research, London.

GHK (2011): Mid-term evaluation of the European Globalisation Adjustment Fund: final report, submitted by GHK to DG EMPL, European Commission, Specific Service Order No VC/2011/ 0207, 8 December.

Grumiller, J. (2014): Ex-ante versus ex-post assessments of the economic benefits of Free Trade Agreements: lessons from the North American Free Trade Agreement (NAFTA), ÖFSE Working Paper No 10, Vienna, URL: http://www.oefse.at/publikationen/policy-notes/detail-policy-note/ publication/show/Publication/ASSESS-TTIP-Assessing-the-Claimed-Benefits-of-the-TransatlanticTrade-and-Investment-Partnership (accessed 1 February 2014).

Kalinova, B., Palerm, A., Thomsen, S. (2010): OECD's FDI restrictiveness index: 2010 update, OECD Working Papers on International Investment, 2010/03, Paris, http://dx.doi.org/ $10.1787 / 5 \mathrm{~km} 91 \mathrm{p} 02 \mathrm{zj} 7 \mathrm{~g}$-en (accessed 24 March 2014).

Laird, S., de Córdoba, S.F. (2006): Coping with Trade Reforms: A Development Country Perspective on the WTO Industrial Tariff Negotiations, Basingstoke, UK: Palgrave Macmillan.

Lawrence, R. (1996): Regionalisms, Multilateralism and Deeper Integration, Washington, DC: The Brookings Foundation.

Myant, M., O'Brien, R. (2014): The TTIP's impact: bringing in the missing issue, Working Paper 2015.1, Brussels: European Trade Union Institute.

Nölke, A., Claar, S. (2012): Tiefe Integration: konzeptuelle Grundlagen, in: Journal für Entwicklungspolitik, XXVIII(2), 8-27.

OECD (2005): Employment Outlook 2005, Paris: OECD.

Raza, W., Grumiller, J., Taylor, L., Tröster, B., von Arnim, R. (2014): ASSESS TTIP: assessing the claimed benefits of the Transatlantic Trade and Investment Partnership, Final Report, 31 March, Vienna, URL: http://guengl.eu/uploads/plenary-focus-pdf/ASSESS_TTIP.pdf (accessed 30 March 2015).

Trefler, D. (2004): The long and short of the Canada-U.S. free trade agreement, in: American Economic Review, 94/4, 870-895.

UNCTAD (2013): World Investment Report 2013: Global Value Chains - Investment and Trade for Development, Geneva: United Nations.

Veugelers, R. (ed.) (2013): Manufacturing Europe's Future, Bruegel Blueprint Series, Volume XXI, Brussels: Bruegel. 